\title{
Avoimuus luo edellytykset osuvampaan metriikkaan - Eva Isakssonin haastattelu
}

Tieteellisen julkaisemisen viittausdatan avoin saatavuus, rikas metadata ja avoimet julkaisut luovat tulevaisuudessa palveluita, joista "ei ole vielä hajuakaan", arvioi Helsingin yliopiston kirjaston bibliometriikkaan erikoistunut tietoasiantuntija Eva Isaksson. Tässä haastattelussa eläkkeelle jäänyt Isaksson kertoo työuransa käänteistä, yhteistyöverkostojen merkityksestä ja hahmottelee julkaisumetriikan kehitystä, avoimen tieteen mahdollisuuksia sekä tasa-arvonäkökulman ja metriikan yhteyksiä.

$\mathrm{H}$ elsingin yliopiston kirjaston tietoasiantuntija Eva Isaksson tunnetaan kansallisesti ja kansainvälisesti työstään erityisesti tähtitieteen kirjastotoiminnan, julkaisumetriikan ja tasa-arvoasioiden parissa. Elokuun lopussa Isaksson jäi eläkkeelle, ja tässä haastattelussa hän kertoo työuransa vaiheista ja ajatuksistaan erityisesti bibliometriikkapalveluiden kehityksestä.

Signum-haastattelua valmistellessa Isaksson oli jo ehtinyt totutella uuteen elämänvaiheeseen. Miten ensimmäiset pari kuukautta ovat sujuneet eläkkeellä?
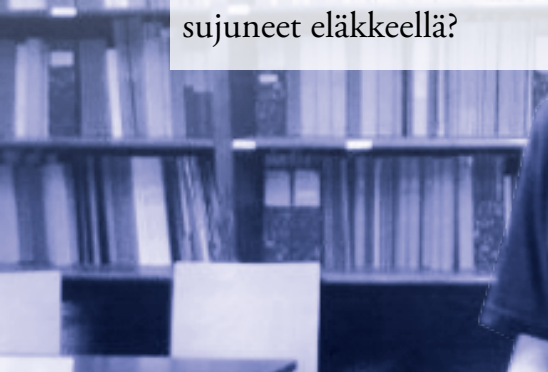

.
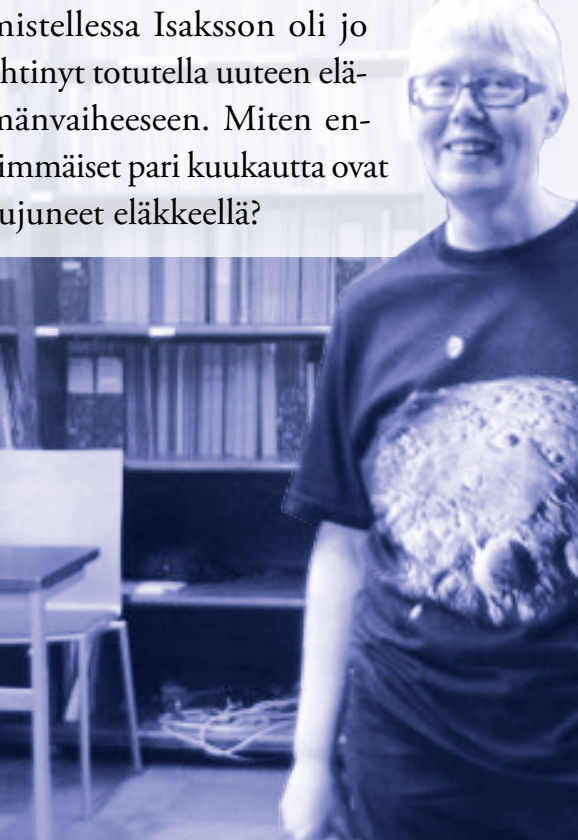

"Ohjelmassa on ollut oman juhlaluennon tallenteen tekstittämistä ja sadonkorjuuta - olen innokas vihannespuutarhuri. Mielessä on ollut jopa kolme eri kirjaprojektia, ja olen näin ensi alkuun odotellut, mikä niistä imaisee mukaansa”, Isaksson kertoo.

\section{Fysiikan opinnoista}

tähtitieteen kirjastonhoitajaksi

Eva Isakssonin tausta on luonnontieteissä, fysiikassa, joka valikoitui omaksi alaksi osittain kuulovamman takia - "matematiikassa kaavat eivät jutelleet". Tie johti kirjastoon,

kun jatko-opinnot piti rahoittaa tähtitieteen kirjaston-

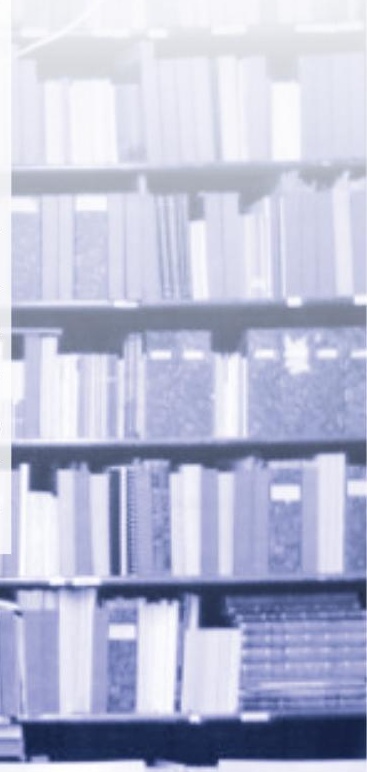

Digitaaliset kirjat monipuolistavat käyttöä, mutta Isaksson toivoo painettujen kokoelmien säilyvän. "Urani parhaita asioita on ollut se, että olen saanut olla tekemisissä painettujen kirjojen kanssa. Selailusta tuleva elämys on ollut yksi kirjastojen vahvimpia asioita." 


\section{8}

hoitajana I980-luvun alussa.

"Sain I98 I teoreettisen fysiikan graduni valmiiksi. Graduohjaajani Raimo Keskinen, joka oli todella mahtava ihminen, etsi aktiivisesti ohjattavilleen työpaikkoja. Ensin ei tärpännyt - ja siksi en tehnyt kirjastoalan työuraani Otaniemessä. Sen sijaan Helsingin yliopiston tähtitieteen laitoksen kirjastossa tärppäsi. Tähtitieteen professori taisi peräti tulla opiskelija-asuntolaan minua värväämään.”

"Aivan ensiksi jouduin käymään lävitse laitoksen massiivisen laitossarjakokoelman, joka on monin tavoin erityinen esimerkki avoimesta tieteestä: kaukana toisistaan sijaitsevat observatoriot lähettivät toisilleen tutkimustuloksiaan ja muita julkaisujaan ilmaiseksi. Niitä kävin aluksi läpi kortiston avulla toista vuotta. Siitä se lähti.”

\section{Rankingeista kohti vastuullista metriikkaa}

B ibliometriikka astui Isakssonin työnkuvaan voimakkaasti 2000-luvun alussa, kun tutkijat alkoivat kiinnostua uusista julkaisudatan analytiikkavälineistä, kuten Web of Sciencesta.

"Jo aikaisemmin olimme tähtitieteessä panostaneet tähtitieteen julkaisujen keräämiseen. Merkittävänä apuna oli tähtitieteen oma bibliografinen viitetietokanta, Astrophysics Data System. ADs oli ensimmäinen avoin tietokanta, jossa viittaukset olivat avoimesti saatavilla. Se aloitti jo
I 990-luvulla, ja sen käyttäjä orientoitui alusta pitäen näkemään julkaisut osana viittausten ja tutkimusdatan verkkoa."

Bibliometriikka on ytimeltään julkaisemista koskevaa tietoa, jota oli totuttu käyttämään myös erilaisten vertailujen ja rankinglistausten tekemiseen. Etenkin lääketieteessä mittaamisella oli pitkät perinteet.

"Lääketieteessä julkaistaan valtavasti, ja siellä on paljon lehtiä. Lääketiede on myös ehkä voimakkaammin kilpailtu kuin esimerkiksi fysiikka. Lääketieteessä kerättiinkin kaikkea viittausdataa ja lehtiä arvotettiin hyviksi ja huonoiksi impact factoreilla (IF). Siellä on jo usean vuosikymmenen ajan sitouduttu siihen, että tutkijan on saatava paljon dataa julkaisemisesta, mikä taas on ohjannut metriikkaa voimakkaasti."

Samalla kun julkaisumetriikan rooli on korostunut muillakin tieteenaloilla, on hämärtynyt se, mitä impaktifaktorit tai Julkaisufoorumi-luokitukset (Jufo) mittaavat: ne on tarkoitettu julkaisukanavien vertailuun, ei tutkijoiden saati yksittäisten tutkimusten arviointiin.

"Metriikassa on monta vuotta työskennelty sen eteen, että tutkijalistaukset saataisiin pois näkyvistä. Jos ne perustuvat lehtien impact factoreihin tai Jufo-tasoihin, kyse ei ole vastuullisesta metriikasta, vaikka tutkijat itse suostuisivat tähän.”

\section{Metriikkapalvelu syntyi keskellä leikkauksia}

Julkaisumetriikan ja tutkimuksen arvioinnin merkityksen kasvaminen on 
vaikuttanut Isakssonin työuran aikana myös palveluihin. Helsingin yliopiston kirjaston keskitetty metriikkapalvelu aloitti vuonna 20 I 5 kirjastoalan vaikuttajan ja tutkimuspalveluiden uranuurtajan Maria Forsmanin aloitteesta.

"Maria oli luonut pohjan metriikkatyölle, mutta hän jäi eläkkeelle 20 I 5 . Samassa yhteydessä kirjastorakennetta uudistettiin, ja tehtiin päätös keskitetyistä tutkimuksen palveluista, joiden osana olisi metriikka. Päädyin vetämään metriikkatiimiä”, Isaksson kertoo.

Samaan aikaan osuivat kuitenkin Helsingin yliopiston leikkaukset, jotka laittoivat metriikan käytön vastuullisuuden toden teolla koetukselle. Yliopistolaisista kerättiin tietoa, ja myös Jufo-tarkasteluista oltiin kiinnostuneita.

"Totesimme, että Jufo-luokitusta ei voi käyttää yksittäisten tutkijoiden tarkasteluun. Tarjosimme korvikkeeksi kullekin tutkimusalalle soveltuvasta tietokannasta poimittuja viittauslukuja. On vaikea sanoa, miten nämä tiedot lopulta vaikuttivat, mutta se oli järkyttävää ja hävettävää, oman urani aallonpohja”, Isaksson toteaa.

Vaikean syntyajankohdan jälkeen metriikkapalvelu on vakiinnuttanut paikkansa kirjaston palveluvalikoimassa, ja kirjastolaisia - Eva Isakssonin johdolla - on osallistunut myös kansalliseen työhön, muun muassa vastuullisen metriikan edistämiseksi.

"Yliopistot ovat kiitettävästi huomioineet vastuullisen metriikan periaatteita ja sitoutuneet DORA-julistukseen.
Elämme kuitenkin vielä välivaihetta, jossa takaiskut rahoituksessa ja resursseissa voivat johtaa siihen, että metriikalta toivotaan apua, kun joudutaan päättämään, mistä leikataan. Viittauksista saatavia indikaattoreita on käytettävä varovasti ja ajatuksella.”

\section{Tutkimuksen arvioinnissa kulttuurillinen murros \\ Y htenä työuransa kohokohdista Isaksson mainitsee osallistumi- sen tutkimuksen arvioinnin} kehittämiseen.

"Helsingin yliopistossa on panostettu todella paljon siihen, että prosessi toimisi ja että saisimme kaikki meille kuuluvat julkaisut kirjattua. Kun tiedämme, mitä julkaisudatassa on, olemme voineet tehdä tarkasteluja tieteenalakohtaisesti. Ei se aina helppoa ole ollut, mutta olen tyytyväinen siihen, että viimeisin arviointi 20182019 meni kuin Strömsössä.”

Arvioinnissa on tapahtunut myös tietty kulttuurillinen murros, kun on alettu entistä paremmin ymmärtää, mitä luvut voivat ja eivät voi kertoa. Tämä on vahvistanut yliopistokirjaston roolia asiantuntijatahona, mutta myös metriikkaa käyttäviltä yliopistolaisilta vaaditaan parempaa ymmärrystä.

"Bibliometriikassa on yhä voimakkaampana trendi, jossa ei etsitä vertailuja, vaan yhteyksiä, eli julkaisemisen sisäistä dynamiikkaa. Tutkimuksen arvioinnissakaan tärkeintä ei ole se, että arvioitavat saavat lukuja itsestään, vaan tärkeintä on se, että he saavat tietoa sii-

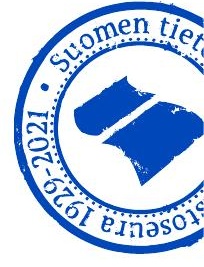




\section{Eva Isaksson}

- Toiminut Helsingin yliopiston kirjaston metriikkaryhmän vetäjänä, julkaisumetriikan kansallisten ja kansainvälisten verkostojen asiantuntijana sekä Helsingin yliopiston tasa-arvo- ja yhdenvertaisuustoimikunnan pitkäaikainen jäsenenä.

- Vastuullisen julkaisumetriikan ja tutkimuksen arvioinnin edelläkävijä ja puolestapuhuja. Isaksson on toiminut pitkään arXiv Member of Advisory Board -jäsenenä ja LISA (Library and Information Services in Astronomy) -konferenssien järjestäjätoimikunnassa.

- Tietokirjailija, julkaissut teoksia mm. tasa-arvon ja rauhanaatteen teemoista (Rauhan laboratoriot, 1985 ja Nainen ja maailmankaikkeus, 1987). Moni teos avoimesti saatavilla Helsingin yliopiston Helda Open Books -kokoelmassa. Suunnitelmissa on jatkoteos Rauhan laboratorioille: "Haluaisin kirjoittaa tutkijoista, jotka ovat tehneet sotaan ja aseiden kehittämiseen liittyvää tutkimustyötä. Mikä on ollut se konteksti, joka on ajanut heitä tähän tutkimustyöhön?"

- Eva Isakssonille on myönnetty Suomen Valkoisen Ruusun ansioristi vuonna 2017, Helsingin yliopiston Maikki Friberg -tasa-arvopalkinto vuonna 1999 ja Tiedonjulkistamisen valtionpalkinto vuonna 1986.

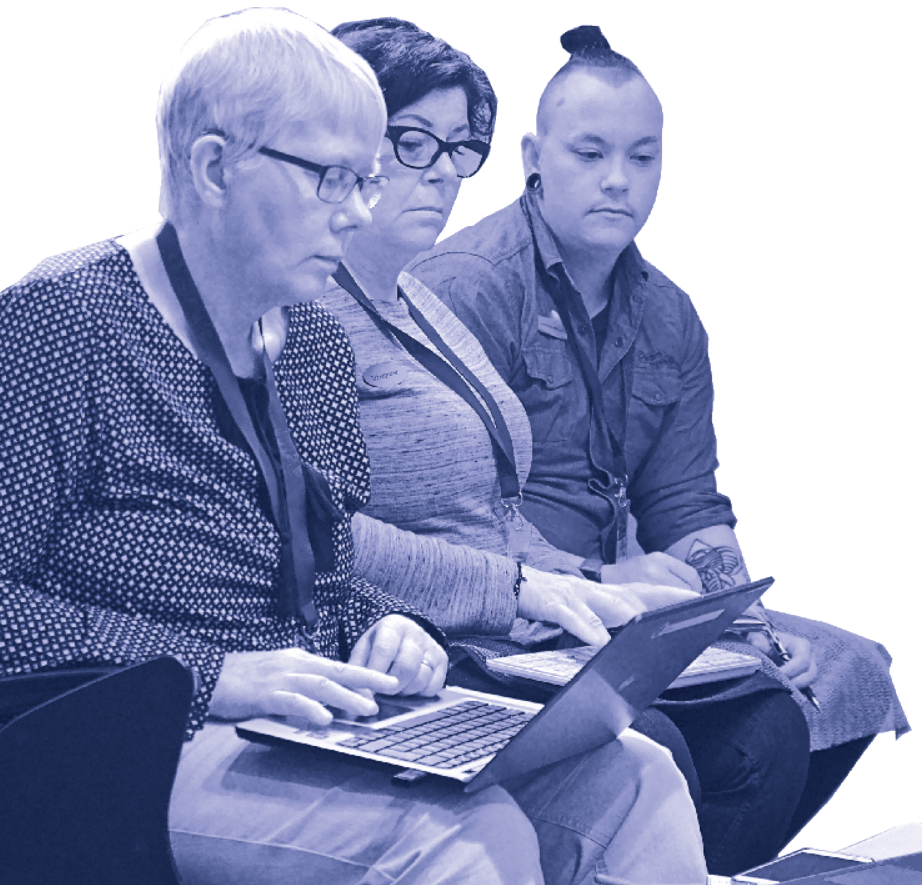

tä, missä kontekstissa heidän tutkimuksensa on tapahtunut. Viimeisimmässä arvioinnissa kävi ilmi, että yksiköissä on paljon vanhentuneita näkemyksiä siitä, mikä metriikan tuottamissa tuloksissa on tärkeää. Siitä sai alkunsa Bibliometriikkaa yliopistolaisille -kurssit, joiden tarkoitus on antaa metriikkaa hyödyntäville ihmisille perustiedot bibliometriikasta”, Isaksson sanoo.

\section{Metriikan vallankumous vasta edessä} erkittävimpänä metriikan välineenä Isaksson mainitsee 20 Io-luvulla ilmestyneet analytiikkatietokannat, joissa tietokantojen koko on mahdollistanut monenlaiset vertailut, trendianalyysit ja klusteroinnit.

Viimeisimpänä trendinä julkaisumetriikassa on ollut viittausdatan avautuminen, mikä Isakssonin mukaan tulee mullistamaan julkaisutoiminnan tarkastelun.

"Kun ennen voitiin katsoa, mitä viittausluettelossa on, tällä hetkellä voidaan tekoälyn avulla katsoa, missä kontekstissa viittaaminen tapahtuu. Rikas metadata ja avoin saatavuus tarkoittavat sitä, että joku jossain kehittää jo tällä hetkellä palvelua, joka tulee mullistamaan näkemyksemme metriikasta. Uskon, että meillä on muutaman vuoden sisällä käytössä palveluita, joista ei ole mitään hajua tällä hetkellä.”

Palveluvalikoiman monipuolistuminen tarkoittaa sitä, että metriikan asiantuntemusta tarvitaan entistä

«Monia kollegoita kiinnostaa, mistä Eva Isaksson saa uskomattoman määrän energiaa, joka näkyy hänen työssään ja persoonassaan. "Kai se on uteliaisuus, joka ei ole hellittänyt vuosien varrella." 
enemmän. Myös julkaisemisen tavat digitaalisessa ympäristössä tulevat muuntautumaan.

"Tästä on tulossa iso viidakko. Meille tullaan tarjoamaan palveluja, lisäosia ja lisää metriikkaa. Tutkijat voivat viehättyä uudesta palvelusta, ja haluavat sen käyttöön. Metriikassa täytyy pystyä tunnistamaan, onko se relevantti, kertooko se oikeita asioita, onko se vakaata dataa - ja ennen kaikkea, kannattaako siitä maksaa."

"Vaaranpaikka on ollut jo pitkään se luulo, että mitä nopeammin tietoja saadaan, sen parempi. Tämähän on altmetriikan sisäänrakennettu ajatus. Silloin ohitetaan se, mikä merkitys julkaisulla oikeasti on, ja missä ajassa sen voi saada selville. Jopa altmetriikassa voi hitaudella olla roolinsa. Todellisen vaikuttavuuden näkee niistä yhteyksistä, joita ei voi saada selville heti.”

\section{Verkostot työn tukena}

saksson on toiminut aktiivisesti sekä kansallisissa että kansainvälisissä verkostoissa. Henkilökohtaisesti tärkeimpänä hän pitää tähtitieteen kirjastoalan kansainvälistä verkostoa, erityisesti LISA-konferensseja (Library and Information Services in Astronomy), jotka tekivät hänestä kirjastolaisen. Kotimaisista keskeisimpänä Isaksson pitää kansallista julkaisumetriikkaverkostoa, joka toimii osana korkeakoulujen ja tutkimuslaitosten laaja-alaista Finn-ARMA-yhteistyöverkostoa.

"Jaamme julkaisumetriikkaverkostossa yliopistojen kesken näkemyksiä ja kokemuksia siitä, mitä bibliometriikassa on meneillään, mitä eri yliopistoissa tehdään ja miten siellä resursoidaan palveluita. Iso asia, joka tänä vuonna on laitettu liikkeelle, on kansallisen bibliometriikkaoppaan toteuttaminen kansallisena yhteistyönä.”

Verkostoissa tehty työ vaikuttaa metriikan kansallisen kehitykseen. Nykyään metriikka kytkeytyy voimakkaasti vastuulliseen tieteeseen ja avoimeen tieteeseen. Isaksson on työllään edistänyt molempia, mutta suhtautuu kriittisesti "sanahelinään”.

"Saatetaan puhua vastuullisuudesta, ja nopeasti luetella, että tehdään näin ja näin, jolloin jo aistii, että ollaan tulosvetoisia. Ajatellaan myös, että kun yhden sijasta käyte-

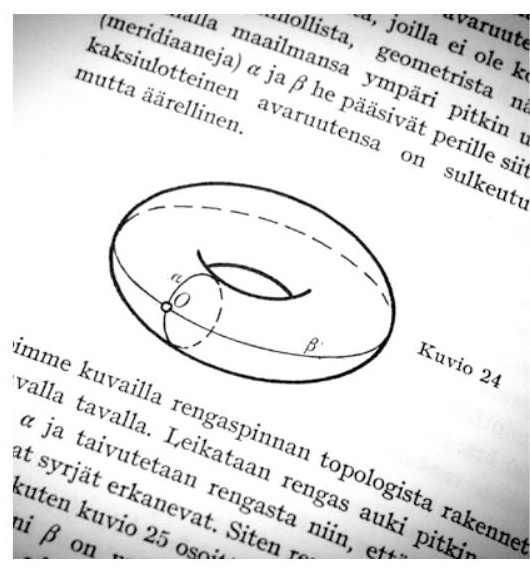
tään viittä indikaattoria, se on sitä vastuullisuutta. Itse näkisin metriikan enemmän avoimen tieteen puolella, johon kuuluu avointen julkaisujen lisäksi avoimet abstraktit, avoimet viittaukset ja avoin data. Jos käytettävissä on mahdollisimman paljon avointa tietoa julkaisuista, voidaan tehdä osuvampaa metriikkaa. Meiltä on vuosien varrella kysytty, voiko tällaisen ja tällaisen tarkastelun tehdä, ja valitettavan usein olemme joutuneet vastaamaan, että ei voida, koska tietokannasta ei saada sitä tietoa irti. Jos data olisi avoimesti käytössä, tilanne muuttuisi voimakkaasti." 


\section{Tasa-arvotyötä 1980-luvulta tähän päivään}

Keskeinen teema Isakssonille on ollut tasa-arvon ja yhdenvertaisuuden edistäminen yliopistomaailmassa. Siinä onkin edistytty.

"Silloin, kun aloitin opiskelut, kuulovammaisilla opiskelijoilla ei ollut mitään tukirakenteita, esimerkiksi nykyistä tulkkaussysteemiä. Piti vain pärjätä. Mitä tulee tasa-arvoon, pitkään oli niin, että asioista päättivät miesprofessorit, jotka eivät nähneet tutkijantyötä naisten työurana. Naistutkijoiden näkyvyys ja naisten tutkimusuran houkuttelevuus on Suomessakin vähitellen lisääntynyt, ja monet sinnikkäät ja näkyvät tiedenaiset ovat toimineet tämän kehityksen kärkinä. Kuitenkin asenteet ja monet rakenteelliset syyt vaikeuttavat edelleen naisten tieteellistä urapolkua.”

Isakssonin omassa julkaisutuotannossa näkyvät tasa-arvon ja rauhanaatteen teemat muun muassa sellaisissa hiljattain uudelleen avoimesti julkaistuissa teoksissa kuin Rauhan laboratoriot (1985) ja Nainen ja maailmankaikkeus (1987), joka antoi lopullisen sysäyksen tasa-arvotyöhön.

Isaksson on 2000-luvun aikana toiminut mukana muun muassa yliopiston tasa-arvotoimikunnassa sekä esteettömyystyöryhmässä, ja hän on ollut valmistelemassa tasa-arvo- ja yhdenvertaisuussuunnitelmia.

"Asioihin on kiinnitetty lainsäädännössä huomiota, ja yliopistossa on etsitty sen toteuttamiseen toimenpiteitä.
Aiemmin tehtiin enemmän selvityksiä ja suunnitelmia, nykyään tasa-arvotyö on enemmän konkreettisia tekoja."

Tasa-arvo- ja yhdenvertaisuustyö sointuu hyvin yhteen myös vastuullisen julkaisumetriikan edistämisen kanssa. Kysymykseen, mitä kaikkien yliopistolaisten tulisi tietää bibliometriikasta, Eva Isaksson vastaa näin:

"Kaikkien pitäisi tietää, että se, missä yliopistossa tutkija on töissä tai missä lehdissä hän julkaisee, ei välttämättä kerro kyseisestä tutkijasta. Se, mitä hän pystyy kertomaan tutkimustavoitteistaan, ja miten hän toteuttaa niitä, kertoo tutkijasta enemmän. Nyt, kun vallalla ovat yliopistorankingit, korostetaan liikaa yliopistokontekstia. Mutta oli ihminen kotoisin mistä maasta tahansa, aloitti hän uransa missä tahansa yliopistossa, oli hän vammainen tai jonkin vähemmistön edustaja - se ei täysin määrittele häntä. Lahjakkaita ihmisiä on kaikkialla. Miten metriikka rajoittaa sitä, mitä ajattelemme ihmisen mahdollisuuksista? Jos etsimme valmiita huippuja, helposti nousevia tähtiä, joilla on hyvät edellytykset päästä nopeasti uran alkuun, menetämmekö jotain? Tätä voisi metriikassa ajatella."

Isaksson kertoi monipuolisen uransa vaiheista myös elokuisessa jublaluennossa Maailmankaikkeus ja kirjasto, joka löytyy Unitube-videopalvelusta: bit.ly/evaisakssoninjublaluento2021.

\section{Juuso Ala-Kyyny}

Helsingin yliopiston kirjasto

juuso.ala-kyyny@helsinki.fi 